\title{
Development of Samiler Jarak-Dolly (SAMIJALI) Business Through Social-Based Business Model
}

\author{
Berto Mulia Wibawa and Andi Hafsah
}

\begin{abstract}
Samijali is a social-based SME in Surabaya. By conveying the economic issue of the Dolly community as the result from the closure of the Dolly prostitution area. However, the high public interest about Samijali is not in line with the business progress that remain slow. The ability of Samijali to develop it's capability is still minimal. In addition, the business model owned by Samijali is still very simple when compared with other sociopreneur business models that have rapid development. The aim of this research is to develop Samijali social business model to help improving the competitiveness, develop suitable branding for Samijali based on evaluated SBMC. This research using qualitative methods with inductiveexploratory research designs. In the research phase, researchers conducted interviews with Samijali stakeholders and business experts to formulate an ideal business model for Samijali. From this research, had been agreed on business model design for Samijali by stakeholders Samijali. Hopefully, this research can help Samijali to grow it's business with the right business model. In addition, this research is expected to make Samijali a rolemodel for social-based SMEs in Surabaya.
\end{abstract}

Keywords-Business Model, Dolly, Samijali, Sociopreneur, SME's

\section{INTRODUCTION}

Samijali is an abbreviated name of "Samiler Jarak dan Dolly" which signifies that this samiler chips came from the Jarak-Dolly area, an area once known as a prostitution localization. Samijali became one of the fastest growing businesses compared to other social-based businesses in the Dolly area. Samijali has a huge social impact for the people of Surabaya. This is because Samijali signifies the rise of the economy of Jarak-Dolly society in a more positive way considering the lack of business growing in the Dolly area that absorbs the workforce in the area. From the side of the local government, especially the Office of Cooperatives and Micro Enterprises of Surabaya, strongly supports the running of business Samijali to stimulate the economy of Dolly people who have withered.

If it is examined on the basis of business development and factors owned, currently Samijali is still in a developing phase. The capabilities possessed by Samijali are good. In terms of sales Samijali already has a website, online marketplace (e.g Bukalapak and Shopee), social media (Instagram and facebook) which is quite complete although

Berto Mulia Wibawa and Andi Hafsah are with Department of Business Management, Institut Teknologi Sepuluh Nopember, Surabaya, 60111, Indonesia. E-mail: berto@mb.its.ac.id. its use is still not optimal. Samijali also has several official resellers and has been working in several franchise gift store in Surabaya. But, the supports from various parties and its current capability are not enough to solve the existing problems. It is proven from the condition of Samijali which until now is still often experiencing loss. One of the things that hampered Samijali's development is that the business model of Samijali is still very simple. This can be seen through the aspects of its existing business model. Although Samijali is a social-based business, but its business model is still absolute entrepreneurship and not yet fully aspect of social-based entrepreneurship business model. There are still many aspects that need to be completed and improved in it. The importance of Samijali's business is directed to a socialbased business model due to the fundamental difference between an entrepreneurship business model and social entrepreneurship. Where the business model of social entrepreneurship is more focused on the social value owned by the business and the development focus is not only oriented with profit alone but also measures the desired impact. Therefore, the fundamental reason of Samijali requires a social-based business model so that Samijali's social values are not lost and become the main focus for Samijali to flourish.

\section{LITERATUR REVIEW}

\section{A. Social Entrepreneurship Concept}

There are two key points in social entrepreneurship. First, the existence of social innovation that can change the existing system in society. Second, the presence of individual vision, creative, entrepreneurial, and ethical behind the innovative ideas [1]. The definition of social entrepreneurship more comprehensively as the creation of social value formed by working with other people or community organizations involved in a social innovation that usually implies an economic activity [2].

Social entrepreneurship is a combination of two words, social meaning socially-oriented and entrepreneurship. Simple understanding of social entrepreneur is someone who understands social problems and uses the ability of entrepreneurship to make social change, especially covering the field of welfare, education and healthcare [3]. The current interest in social entrepreneurship is increasing because of the social entrepreneurship shift which was originally considered to be a "non-profit" activity (among 
other things through charity) into business-oriented activities [4].

\section{B. Social Based Business Model}

Business model is a basic idea of how an organization creates and delivers value. The business model is believed to be very well explained through nine basic building blocks that show how to think about how a company makes money [5]. While, Social Busineess Model Canvas (SBMC) is a form of business model inspired by the business model canvas (BMC) created by Social Innovation Lab (2013), with the goal of supporting innovators and business people in the social field by designing their business models. social businesses focus on their impact in creating the benefits they get compared to the benefits they make. Therefore, the tool adds several aspects that help in creating a social-based business model. in SBMC is divided into 13 columns. There are:

1. Segments: Describe a group of different people or organizations that the company wants to reach or serve. In Segments column, divided into beneficiary and customer. This supports the benefits that are often not financially profitable but have a crucial value to the business model.

2. Value Propositions: consists of social value, value of customer, and impact, which defines how we can control the social impacts it has.

3. Type of Intervention: describes the type of product to be delivered value such as the type of goods to be sold in the business to be performed

4. Channels: Describe how a company communicates with its customer segment and reaches them to provide value proportions.

5. Customer Relationships: Describes the different types of relationships that a company builds with a specific customer segment.

6. Revenue Streams: Describe the cash generated by the company from each customer segment.

7. Key Resources: Describe the most important assets needed for a business model to work.

8. Key Activities: Describes the most important things to do in order for the business model to work.

9. Key Partner: Describe a network of suppliers and partners that make business models work. In addition to the key partner column, this tool includes stakeholders who should be involved in the program they have

10. Cost Structure: Describe all costs incurred to operate the business model.

11. While in the surplus column explain how our plan to invest profits owned

\section{RESEARCH METHODS}

This research was conducted on February until July 2018 (Fig. 1). The method used in this research was explorative research design type. Explorative research was a type of research conducted when there is no or little study of

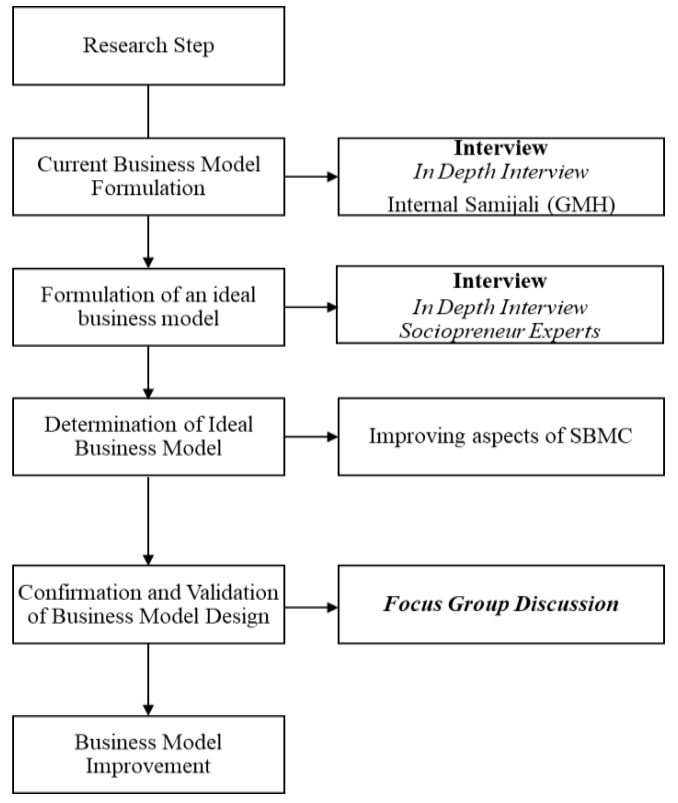

Figure 1. Research Steps.

research on a problem [6]. The type of approach used was qualitative inductive approach. The inductive approach was emphasized research on observations first, then summarized the solutions to be offered based on those observations [7]. Qualitative method is chosen as a research procedure that produced descriptive data in the form of written or oral words of persons and observable behavior. This approach was directed to the background of the individual holistically [7].

The first step is mapping Samijali business model in accordance with the information and data that had been obtained through the interview process with the manager or person-in-charge for Samijali from NGO Gerakan Melukis Harapan $(\mathrm{GMH})$ at recent time. The interview technique used in this process was in-depth interview. In-depth interview investigated deeply into a predetermined topic (based on the purpose and intent of holding the interview) using open-ended questions [8].

The next step is to formulate an ideal business model for Samijali. At this stage, some steps were taken to get various references on how the business model needed to be developed by Samijali. The technique of business model formulation used two ways, among others was evaluation of current business model and interview with some experts of sociopreneur in Surabaya City. In this research, the evaluation model that was used was Stake Evaluation Model. In this stage, the evaluation of the current business model was needed to find out which aspects needed to be addressed and improved from the thirteen (13) aspects contained in the social business model canvas (SBMC). At this stage, Samijali's business aspect ranking was based on the level of importance that needed to be improved as soon as possible so that Samijali could survive in the market examined by expert opinion. 
International Conference on Engineering, Advance Science and Industrial Application (ICETESIA) 2018

September 6-7 2018, Institut Teknologi Sepuluh Nopember, Surabaya, Indonesia

After formulating an ideal business model for Samijali, the next step was to establish the concept of a social-based business model. This was done in order to determine the business model according to the characteristics and needs of Samijali. The concept of a business model was designed based on the criteria that had been identified in the previous stage. Determination of the concept was also based on secondary sources that came from some previous research. In determining the concept of Samijali's business model, SBMC reference that was used had been developed by social lab innovation (2013). Furthermore, some improvements had been made to the aspect of the business model in accordance with the advice that was given by the sociopreneur expert on the good business model for Samijali in the future.

After doing business model design, the next step was to confirm and validate previous designs on the stakeholders of Samijali. This was done in order to design the new business model and its description in accordance with the principles and capabilities that Samijali had to execute the strategy. Confirmation of data would be done with focus group discussion technique (FGD). The purpose of the FGD was to explore a specific problem, related to the topic being discussed. FGDs were used to draw conclusions on intersubjective meanings that were difficult to be given their own meaning by the researcher because they were hindered by the subjectivity of the researcher [5]. After confirmation and validation of business model using focus gruop discussion technique (FGD) to stakeholder of Samijali, the result was evaluation and revision of Samijali business model design. The next step was to revise the business model design as a result from evaluation by Samijali stakeholders to be designated as the final draft.

\section{RESULT AND DISCUSSION}

\section{A. Samijali Business Model In Existing Condition}

To understand Samijali current business model, an indepth interview was conducted with 2 resource persons selected based on purposive technique. At this stage, the researcher exploring information about how Samijali's performed its business from upstream to downstream, to get the aspects of business model run by Samijali at the moment. In evaluating Samijali's business model, the researchers conducted interviews with three resource persons who were social-entrepreneurship. Business model evaluation was done by giving questions about the ideal business model criteria, followed by evaluation of every aspect of Samijali business model by every resource person.

\section{B. Designning New Model Business}

The following table was the result of opinion and level of urgency of improving the aspect of Samijali's business model based on expert opinion on interview (Table 1). Based on the results of the interview, it could be concluded that some things needed to be changed, among others were value proposition, segments, type of intervention, channel, key activities, key resources, partners and stakeholders, surplus and revenue stream.

TABLE 1.

BUSINESS MODEL EVALUATION RANK BASED ON EXPERT OPINION

\begin{tabular}{llll}
\hline \hline \multicolumn{1}{c}{ Expert 1 } & \multicolumn{1}{c}{ Expert 2 } & & \multicolumn{1}{c}{ Expert 3 } \\
\hline 1) Customer segment & 1) Key activities & 1) Value proposition \\
2) Surplus & 2) Value proposition & 2) Type of \\
3) Segments & 3) Revenue stream & & intervention \\
4) Key Activities & 4) Key resources & 3) Key resources \\
5) Channel & 5) Partners + & 4) Key activities \\
6) Beneficiary & stakeholder & 5) Channels \\
7) Revenue & 6) Type of & 6) Surplus \\
& 7ntervention & 7) Revenue stream \\
& 7) Segments & \\
\hline \hline
\end{tabular}

1. Value Proposition

The value proposition aspects that were addressed including social value and impact measure.

a) Social Value

The social value of a good entrepreneurial endeavor was to elevate the positive impact of a business. Therefore, it would be better if Samijali did not continue to carry "Dolly's flag" to gain public attention and attract community empathy. In addition, Social values that exist in social entrepreneurship should contain sensitivity. Therefore, the social value that Samijali possess needed to be transformed into a more positive statement, but still had an element of sensitivity. In the new social values, researchers initiated that the main character in the social value was not Dolly but the people who wanted to change in a positive way through Samijali. This alteration of meaning was aimed at bringing the social value through a positive impression to Samijali's consumers. In addition, the social values were designed not to give the impression that Samijali's business was a class of affected people who always needed to be helped. The use of words was chosen in order to give the impression that members of Samijali were able to survive and develop positively after the closure of Dolly's localization. In the new social values, it was expected to show Dolly community's determination to change through Samijali business. (Table 2)

TABLE 2.

COMPARISON BEFORE AND AFTER SOCIAL VALUE ChANGES

\section{Social Value}

Current Condition

Help improve the economy of

Jarak and Dolly communities in a positive way

Proposed Design

Stimulate the economy of Jarak and Dolly communities through Samijali's business activities

\section{b) Impact Measure}

The impact of a social object could be seen from the level of concern of social objects with social-enterprise. In addition, impact measurement could also be identified through the dependence of social objects with existing social-enterprise. An ideal social enterprise must have a clear impact. where there was a significant change in the environment or behavior of social objects. In measuring the impact on Samijali's current business model, impact 
measurements were not yet clear and there was no strong dependence between Samijali business and its members. This was because the income from the Samijali business was only made into additional revenue by its members. Thus, the investigator initiated into impact measurement and a clear attachment between members of Samijali and Samijali business itself. Changes in the impact measure were as follows. (Table 3)

TABLE 3.

COMPARISON BEFORE AND AFTER IMPACT MEASURE CHANGES

\begin{tabular}{|c|c|}
\hline \multicolumn{2}{|c|}{ Impact Measure } \\
\hline Current Condition & Proposed Design \\
\hline $\begin{array}{l}\text { - There is a steady income } \\
\text { for Dolly people who join } \\
\text { with Samijali } \\
\text { - Increase in the amount of } \\
\text { income }\end{array}$ & $\begin{array}{l}\text { - Samijali became the main } \\
\text { work for the people of } \\
\text { Distance and Dolly who } \\
\text { joined through: } \\
\text { - } 80 \% \text { of Samijali's business } \\
\text { activities are carried out by } \\
\text { the people in the area } \\
\text { - Upstream-downstream } \\
\text { business development }\end{array}$ \\
\hline
\end{tabular}

In its development, Samijali needed to absorb more labor in its place in order to provide more benefits to more people in the region. Therefore it needed for larger business process in order to absorb more labor in the area. The next problem facing Samijali was its reliance only on one raw material supplier. In addition to eliminate characteristics and flavors in a product, reliance only on one supplier alone could pose a threat to the business itself [9]. The solution that was offered was the development of upstreamdownstream businesses. This could help improve the workforce for people in Jarak and Dolly area and could enlarge Samijali business itself.

2. Segments

In the social-based business model, segments aspects that were addressed including consumer and beneficiary

a) Consumer

TABLE 4.

COMPARISON BEFORE AND AFTER SEGMENTS CHANGES IN CONSUMER

\begin{tabular}{ll}
\hline \hline \multicolumn{1}{c}{ Current Codition } & \multicolumn{1}{c}{ Consumer } \\
\hline - Any People & Segmentation: \\
- Tourists & - Middle-Class Society \\
- Locals & - Age of 19-60 year old \\
- College Students & - Live Outside Surabaya \\
& Targeting: \\
& - Tourists \\
& - College Students \\
& - People who like samiler before \\
\hline \hline
\end{tabular}

In the consumer (customer) aspect, it needed a clear segmentation in accordance with existing theory. It was necessary so that businesses knew clearly who would buy their products and what they wanted to convey through the products they made. In the customer aspect, Samijali was still mapping their customers widely, resulting in less focus Samijali to position itself to the consumers they had. Therefore, the researcher concluded the tendency of Samijali consumer based on interview resulted by Samijali stakeholders and then it was formulated into the segmentation and targeting model [10] (Table 4). The redesign of consumer segmentation Samijali was expected was to help them specifying the consumer from Samijali, and was given an impact of the easier Samijali in determining the marketing strategy in accordance with the interests and conditions of its target consumers.

b) Beneficiary

TABLE 5 .

COMPARISON BEFORE AND AFTER SEGMENTS CHANGES IN BENEFICIARRY

\begin{tabular}{ll}
\hline \hline Current Condition & \multicolumn{1}{c}{ Beneficiary } \\
Proposed Design
\end{tabular}

The scope of the beneficiaries of Samijali was too broad and unfocused. For social companies, the beneficiary's focus was crucial for delivering value as well as what was expected. On the other hand, "If Samijali wanted to make the Jarak and Dolly communities as beneficiaries, Samijali should not be closed and made the membership open to the Jarak and Dolly community who wanted to take part in its business activities. (Table 5). The opening of membership in Samijali, originally only in the alley of Putat Jaya IV A, aimed to absorb more work teams in Jarak and Dolly region. In addition, the development of upstreamdownstream business required more labor and if it still used a closed member system, the business development process was difficult to be implemented. Therefore, in the member recruitment for Samijali it was proposed to open up to touch any area other than Jarak and Dolly.

3. Type of Intervention

TABLE 6.

COMPARISON BEFORE AND AFTER TYPE OF INTERVENTION CHANGES

\begin{tabular}{|c|c|}
\hline \multicolumn{2}{|c|}{ Type of Intervention } \\
\hline Current Condition & Proposed Design \\
\hline $\begin{array}{l}\text { - As a sales and marketing partner } \\
\text { for the Dolly community in the } \\
\text { development of Samijali products } \\
\text { - Provide value to samiler crackers } \\
\text { and make them specialty of the } \\
\text { region with the brand Samijali }\end{array}$ & $\begin{array}{l}\text { - Provide the latest features for } \\
\text { Jarak and Dolly areas as } \\
\text { Samijali producing areas } \\
\text { - Provide added value to samiler } \\
\text { crackers and make it a regional } \\
\text { specialty with brand Samijali }\end{array}$ \\
\hline
\end{tabular}

The kind of intervention that was good for a social enterprise must contain the value that rose in all aspects of the business chain it had. This was because there was a need for a common mission to deliver the same value in a social enterprise. In addition, "The ideal social enterprise must be able to conduct business from upstream to downstream in order for the business to have specialty and absorb more social objects than any other business. In addition, "Interventions with great influence should be able to describe the social value of the area. From the results of the interview, in re-designing aspects of the type of intervention that Samijali had, researchers had included elements of upstream-downstream business development 
International Conference on Engineering, Advance Science and Industrial Application (ICETESIA) 2018

September 6-7 2018, Institut Teknologi Sepuluh Nopember, Surabaya, Indonesia

that eventually resulted in a strong product specialty of the area. (Table 6)

\section{Channel}

The growing number of sales media could make it easier for consumers to find their own products. And also could stimulate the sustainability of the social enterprise. the marketing channel performs the task of moving goods or services from producers to consumers. Companies need a distribution channel for marketing their products, because distribution channels have a very important role in marketing itself. "The proper use of sales media was to follow the customary preferences of targeted consumers. The company must actually select or filter the distribution channel/distributor that would be used, because the error in the election might hinder the business in distributing goods or services.

TABLE 7.

COMPARISON BEFORE AND AFTER CHANNEL CHANGES

\begin{tabular}{ll}
\hline \hline \multicolumn{1}{c}{ Current Condition } & \multicolumn{1}{c}{ Channel } \\
\hline - Small Business Center Surabaya & - Small Business Center Surabaya \\
(Merr, Siola, Pelindo, Juanda) & - Specialty Shop Surabaya \\
- Specialty Shop Surabaya & - Retail store \\
- Social Media & - Tourism Spot \\
(IG, Line@, bukalapak) & - Social Media \\
& - Market place online \\
\hline \hline
\end{tabular}

In the redesign of Samijali's business model, several sales media targets were added to develop the distribution channel owned by Samijali. In addition, because one of the target consumers Samijali was tourists, who came to the place of tourism was recommend as media sales by using co-branding. It was intended that Samijali better known by tourists who came in Samijali as souvenirs typical area in Surabaya. In subsequent targets, Samijali's sales medium added minimarkets, retail-stores, and tourism places to distribute its products (Table 7).

5. Key Activities

TABLE 8.

COMPARISON BEFORE AND AFTER KEY ACTIVITIES CHANGES

\begin{tabular}{ll}
\hline \hline \multicolumn{1}{c}{ Current Condition } & \multicolumn{1}{c}{ Key Activities } \\
\hline - Production & - Production on a regular basis \\
- Product restock & - Development of a social-based \\
- Human Resource & business system \\
Development & - Product development \\
- Visit from Surabaya City & - Human Resource Development \\
Government & - Marketing \\
& - Expansion \\
\hline \hline
\end{tabular}

To develop a social business into a professional business, routine activities should follow similar companies that had reached the stage of success/benchmarking. From benchmarking results, an organization could gain insight into the organization's performance condition so that it could choose the best choice to achieve the desired target. Until now, Samijali's routine activities were still very simple and needed for benchmarking on similar companies to develop routine activities owned by Samijali. The main benchmarks of Samijali in implementing benchmarking based on expert recommendations were Maicih and Segoe Jamoer. (Table 8)

6. Key Resources

A good social enterprise was owned and recognized by public. Not owned by a group of people alone. Samijali was branding itself as an effort from the community of Jarak and Dolly. However, until now there had been no signs indicating that Samijali would recruit members outside the alley of Putat Jaya IV A. If in the previous business model Samijali considered less absorbing employment in its own area. So the recruitment of Samijali members must be done. In addition, significant changes were needed through member recruitment so that the true goals of Samijali could be achieved correctly. Another reason for open membership recruitment for Samijali was to support previously planned upstream-downstream business processes. If this was not done, then Samijali's condition would continue to be in the same position and not progress significantly. (Table 9)

TABLE 9.

COMPARISON BEFORE AND AFTER KEY RESOURCES CHANGES

\begin{tabular}{lc}
\hline \multicolumn{1}{c}{ Current Condition } & Key Resources \\
People in the alley of Putat & \multicolumn{1}{c}{ Proposed Design } \\
Jaya IV A who join & $\begin{array}{l}\text { Jarak and Dolly communities who are } \\
\text { divided into groups to support operations } \\
\text { from upstream-downstream }\end{array}$ \\
\hline \hline
\end{tabular}

\section{Partners and Stakeholder}

To develop Samijali business so it could be more known to the people of Surabaya and the surrounding areas, researchers initiated the implementation of cooperation in Surabaya society to become reseller Samijali. In addition, to strengthen Samijali's marketing and to touch the interest of the young community, it was necessary to develop intensive website and social media for Samijali. (Table 10)

TABLE 10.

COMPARISON BEFORE AND AFTER PARTNERS AND STAKEHOLDER CHANGES

\begin{tabular}{ll}
\hline \hline \multicolumn{1}{c}{ Current Condition } & \multicolumn{1}{c}{ Partners and Stakeholder } \\
Proposed Design
\end{tabular}

8. Cost Structure

TABLE 11. COMPARISON BEFORE AND AFTER COST STRUCTURE CHANGES

\begin{tabular}{ll}
\hline \multicolumn{1}{c}{ Current Condition } & Cost Stucture \\
\hline - Purchase of raw materials & \multicolumn{1}{c}{ Proposed Design } \\
- Production & - Production \\
- Product distribution & - Product Test \\
- Labor wages & - Product development \\
& - Marketing \\
& - Product distribution \\
\hline \hline
\end{tabular}


The cost of spending was a reflection of the activities undertaken by a business. Ideally, if a business had grown rapidly then the activities undertaken would also increase. As there were additions in Samijali's main activity to the new business model, there was a change in cost strucutre in this design. (Table 11)

9. Surplus

Social enterprises should have other social activities. Not just a social object only. Given the social development with that model, the existing social values would continue. In the distribution of profits owned by Samijali, it should be divided into 3 parts, among others, was the development of business Samijali; retained earnings for Samijali; and social funds that would be raised by Samijali. If previously the benefits that was obtained by Samijali was not maximized well and only distributed to members then the recommendation would be needed for Samijali's own business development. (Table 12)

TABLE 12.

COMPARISON BEFORE AND AFTER SURPLUS CHANGES

\begin{tabular}{ll}
\hline \hline \multicolumn{1}{c}{ Current Condition } & \multicolumn{1}{c}{ Surplus } \\
\hline - Production & \multicolumn{1}{c}{ Proposed Design } \\
- Labor wages & - Development of Samijali business \\
& line \\
& - Human Resource Development \\
& - Social development undertaken by \\
& Samijali \\
\hline \hline
\end{tabular}

10. Revenue Stream

Social enterprises were not allowed to make grant funds as one source of income. Although social entrepreneurs made social as one of many factors that establish the business. However, an entrepreneur must rely on the sale of his product as the greatest income earned by it. Therefore, if Samijali still relied on grant funds as one of its revenue source, it was better to keep the grant money for Samijali's needs. Not for personal gain.

To propose an alternative source of income for Samijali, a simple survey related to the characteristics of Samijali was conducted based on expert opinion. Therefore, the researchers proposed that Samijali had a product line other than food to introduce the story of Samijali to society. In addition, the development of the product line was intended to allow Samijali to have another income from selling its chips. The products proposed in the category of product lines were products that could be stored but still used as souvenirs or specialty of Surabaya such as clothes, key chains, or tumblr. To minimize the risk that Samijali might experience shortage of capital someday. Researchers suggest the holding income in the form of investment. This was intended for Samijali to have a preserved fund that still be used to produce for its members. (Table 13)

TABLE 13.

COMPARISON BEFORE AND AFTER REVENUE STREAMS CHANGES

\begin{tabular}{ll}
\hline \hline \multicolumn{1}{c}{ Current Condition } & \multicolumn{1}{c}{ Revenue Stream } \\
\hline - Sales & - Samiler's Sales \\
- Grant Fund & - Profit on hold invested \\
& - Souvenir sales in other forms \\
\hline \hline
\end{tabular}

\section{Confirmation and Validation of Business Model Design}

After designing a business model for Samijali, the next step was to confirm and validate the business model design that had been created. Validation was done by using focus group discussion (FGD) method. Where after the FGD, there would be obtained a results in the form of agreement and correction of design between stakeholders Samijali with researchers. The purpose of the FGD was to confirm and validate the design of business models by researchers to stakeholders of Samijali. So the results of FGD could be used as an evaluation of the improvement of the business model. Then it was obtained the following results:

1. Stakeholder Samijali accepted the business model design proposed without any change

2. Stakeholder Samijali asked for development milestone of Samijali for the next 5 years. Milestone could be a business road map for easy understanding. It aimed to facilitate Samijali in realizing the business model that had been designed previously

\section{CONCLUSION AND IMPLICATION}

Designing a business model based on social to get 13 aspects in it. The new SBMC concept put forward the concept of upstream-downstream business development, which at this stage has several strategies such as recruiting new member, development, and operational development conducted by Samijali. In addition, the new SBMC development concept is expected to provide a strong characteristic for Samijali and provide a positive aura on Samijali's social business.

Applied from this research can be used to develop Samijali and as development for similar businesses. For Samijali, it would be better if the application of the new business model is also accompanied by an increase in capacity and capability for short and long periods of time. It is necessary for the application of business model can be done maximally. Several things that Samijali can do to improve capacity and capability of his business:

1. Strengthening the business base. It is necessary for Samijali to make it easy to conduct business activities. Where it is not hampered by licensing in business development, having a fixed place of business, along structuring and a clear working system

2. Human resource development. Human resource development is needed to improve Samijali's business capability in the short and medium term. Therefore, Samijali need to conduct training and professional development to improve the ability of human resources owned.

3. Development of operational and distribution systems. This activity must be implemented by Samijali to equate its business activities with the SBMC that has been designed previously.

\section{LIMITATIONS}

Some of the limitations of this study are: 
International Conference on Engineering, Advance Science and Industrial Application (ICETESIA) 2018

September 6-7 2018, Institut Teknologi Sepuluh Nopember, Surabaya, Indonesia

1. This design does not take into account of cost aspects.

2. Only based on the opinion of the experts to formulate business models that addressed.

\section{REFERENCES}

[1] L. Hulgard, "Discourses of Social Entrepreneurship-Variations of The Same Theme," EMES Eur. Res. Netw., vol. 10, no. 1, pp. $3-18,2010$.

[2] W. Cukier, S. Trenholm, D. Carl, and G. Gekas, "Social Entrepreneurship: A Content Analysis," J. Strateg. Innov. Sustain., vol. 7, no. 1, pp. 99-119, 2011.

[3] B. Drayton, "The Citizen Sector: Becoming as Entrepreneurial and Competitive as Business," Calif. Manage. Rev., vol. 44, no. 3, pp. 120-132, 2002.
[4] P. Kotler and K. L. Keller, Manajemen Pemasaran. Jakarta: Erlangga, 2009.

[5] A. Osterwalder and Y. Pigneur, Business Model Generation: A Handbook For Visionaries, Game Changers, and Challengers. New York: John Wiley \& Sons, 2010.

[6] N. Malhotra, Marketing Research: An Applied Orientation, 6th ed. New Jersey: Pearson Education, 2010

[7] L. Moleong, Metode Penelitian Kualitatif. Bandung: Remaja Rosda Karya, 2007.

[8] M. Porter, "How Competitive Forces Shape Strategy," Havard Bus. Rev., pp. 137-145, 1979.

[9] S. Kresno, E. Nurlaela, E. Wuryaningsih, and I. Ariawan, "Aplikasi Penelitian Kualitatif Dalam Pemantauan dan Evaluasi Program Kesehatan,” Depok, 1999.

[10] H. Utomo, "Menumbuhkan Minat Kewairausahaan Sosial," Among Makarti, vol. 7, no. 14, pp. 99-119, 2014. 